

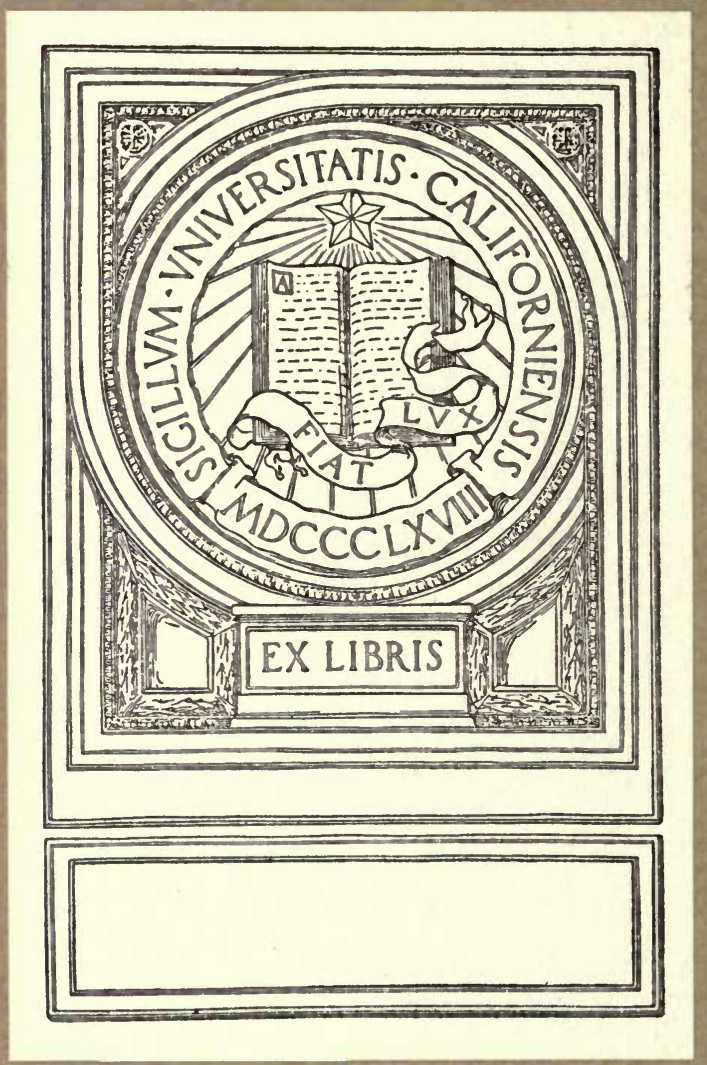




\title{
MichigAn ACADEMy OF SCIENCE
}

\author{
PRESIDENTIAL · ADDRESS
}

ON

\section{A NATURAl History SURVEy OF MICHIGAN}

BY

\section{VOLNEY M. SPALDING}

ANN ARBOR, APRIL $x, x 898$.

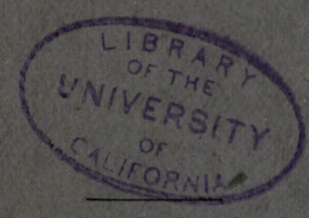

THE INLAND PRESS

ANN ARBOR, MICH. 


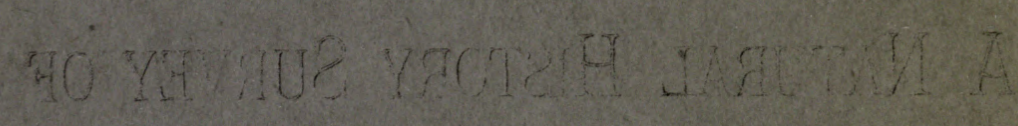
whingrim

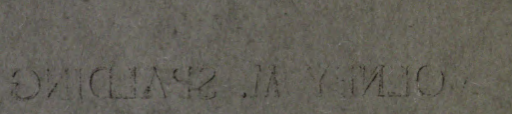




\section{Michigan ACAdemy of Science}

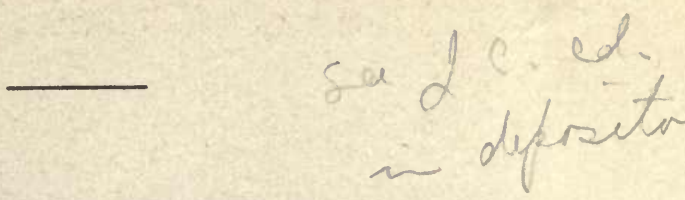

Presidential AdDRESS

ON

\section{A Natural History Survey of MICHIGAN}

BY

\section{VOLNEY M. SPALDING}

ANN ARBOR, APRIL ז, 1898.

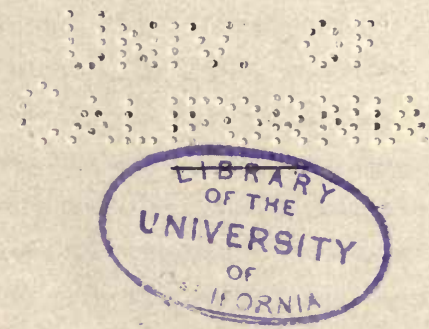


QH 105

M5S6

$\because \because \because \because \because \because \vdots \vdots \vdots \vdots \vdots \vdots \vdots \vdots \vdots 0$

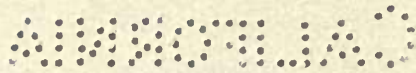




\title{
A Natural History Survey of Michigan,
}

\author{
Professor Volney M. Spalding.
}

In Michigan, as in many other Statss the desirability: or, perhaps better, the necessity of a sunyey of the natural resources of the State was early recognized.., n 1837 Gaverne Mason approved an act providing for a geological, zoological, botanical and topographical survey.

It is of interest to note that the early surveys, or explorations, that followed were not limited to a study of the mineral wealth of the Territory. The flora of the regions visited occupied no inconsiderable part of the time and attention of the explorers, and Dr. Houghton's plants in the University herbarium are, many of them, after the lapse of over half a century, still among the finest in the collection. Economical considerations, however, soon led (1840) to the repeal of those portions of the act that pertained to zoology and botany, and but little more was undertaken in this direction until the survey of 1859 and 1860 , the report of which, transmitted by Professor Winchell, in 1860, included geology, zoology and botany, the zoological part consisting of an enumeration of birds, reptiles, batrachians and mollusks, while the part devoted to botany includes a list of vascular plants, with remarks on distribution and economical relations.

Since that date the survey has been geological. Its scientific and practical value are not questioned, but it is at least an open question whether a return to the more comprehensive plan of the original promoters of the survey is not desirable, and whether there is any reason to suppose that at the pres. ent time there are under the earth in Michigan things about 
which it is more important for us to know than it is to know about those in our waters and in our forests.

The practice of other States may be expected to throw some light on this question. Our neighboring State of Ohio has published, as part of its voluminous report of the Geological Survey, a large volume on the zoology of the State, in which the honored and lamented Chief of the Survey, Dr. J. S. Newberry, takes occasion to speak at some length of the educational and practical value of this part of the work; and Indiana, in its survey by counties, has made large provision for the study of the plant-life of the State, with the object, amorg other things, of preserving, for future generations, a permanent record of the flora as it now exists.

New York State many years ago made appropriations for the natural history side of its survey, and has continued this liberal policy to the present time, and the recent reports of the Geological Survey of New Jersey give large space to the report of the botanist, while Pennsylvania has recently organized a comprehensive survey of its forest resources, and States farther south have set an example which we may well consider. The work of the Alabama Biological Survey comes to us as an example, with the ripe fruits of the long and welldirected activity of that rare scientific genius, Dr. Charles Mohr, and with a corps of younger men eagerly pushing forward into fields that still in Michigan wait our explorations. Can it be that the atmosphere of the Gulf is more invigorating to workers in science than that of the Lakes?

But in some of the newer States of the West we find a still fuller realization of the broad views and more comprehensive plans that, partly in the light of experience and partly as the result of a growing conviction of the inter-dependence of all organic science, have been embodied in the practical workings of the State Surveys. In Minnesota the Survey was organized as late as 1872. It was named-and the name is significant-The Geological and Natural History Survey of Minnesota, and was placed under the direction of the Board of 
Regents of the University. "The Survey is comprehensive in its scope. The fields of investigation named in the original act are geology, botany, zoology and meteorology." * The results of the investigations already made include so many bulletins, scientific papers and reports that an enumeration would occupy too much time, but they stand as witness to the liberality and breadth of view with which this Survey has been conceived and so far carried out, and we may congratulate the people of our vigorous sister State on "the steadiness of purpose that has held the Geological and Natural History Survey of Minnesota to its work."

It is, perhaps unnecessary to go further, although other examples are not wanting of the fact that States characterized by generous and enlightened views have provided, and are now providing, means for surveys not limited by the bounds of a single science, in which plant and animal life are recognized as being quite as worthy of study as the mineral wealth of the State.

Unfortunately, this is not true of our own State. Former papers before this academy have not failed to emphasize the patent fact that Michigan, so far from being a leader among the States in organized biological work, conducted by the State, is far behind others that started later; and the fact that a special committee appointed for the purpose of securing appropriations from the Legislature for printing the publications of the Michigan Academy of Science has thus far met with no success may well lead to careful seeking after the cause of this apparent indifference. Are we producing nothing worthy of the attention of the State? Or is our work good enough in its way, but of no money value, and consequently something that the public money ought not to be spent for? Or is there some occult reason, not yet suggested, for a condition of affairs that, to say the least, is not creditable to the State of Michigan or to the scientific workers within its borders?

* Hall C. W. The University of Minnesota, an Historical Sketch. Minneapolis, 1896. 
Without attempting here and now to discuss these questions, it is enough to say that, however far from our ideal the record of the past has been, present opportunities constitute an imperative call to present duty. There are certain press. ing problems of both economical and scientific interest to which we should address ourselves.

In Michigan two such problems are presented by our forests and fisheries. It is to the former that I wish for a short time to direct your attention. The facts are familiar, but I am sure that those who have already done so much in this direction are the very ones who will most gladly listen, if by any means we may at length see more clearly and take some actual forward steps toward the working out of the great problem involved in the future of our.Michigan forests.

The pine belt of Michigan formed in its day part of one of the finest natural forests on the face of the earth, with its magnificent cork pines hundreds of years old, towering above equally beautiful specimens of sugar maple, basswood, rock elm and other deciduous trees, constituting the beautiful growth of hard wood that still covers so many square miles of northern Michigan. It was a forest that did not grow in a day. It takes about two hundred years for a white pine tree to come to maturity, and many of those cut by Michigan lumbermen were much older, so that when lumbering was commenced in the State one of its great natural resources that had been hundreds of years in making changed rapidly into another form of wealth and disappeared. 'The later history is familiar to you. Year after year saw gigantic lumbering operations farther and farther extended, and fearful fires sweeping through the débris, carrying thousands of acres of virgin forest to its doom, with the homes and hopes of settlers, leaving such a picture of desolation as haunts the memory of one who has passed through it, all the more appalling because of the tragic wreck of human interests, and the apparently hopeless outlook for the future.

It is well for us servants of the State, even if devotees of 
pure science, to try and form some conception of the magni. tude of an interest that has been so conspicuous an element in the material development of the Commonwealth. Briefly, then, as early as 1881 the aggregate value of the forest products of the State was estimated to have reached more than a billion dollars, and now after half a century of lumbering, and after the closing of one great mill after another and removal of the operators to other fields, the State of Michigan alone produced in $1897,2,335,000,000$ feet of lumber and $1,284,000,000$ shingles. These figures may produce no real conception of what they stand for, but they may help us in some measure to appreciate the fact that the prosperity of the State has been due very largely, if not chiefly, to its forests, and that the State must inevitably suffer a loss not easily estimated through the certain diminution of this great source of wealth.

We may now raise the question whether all this is any concern of the State, whether as a Commonwealth it is under any obligation to seriously take up the question of forest reserves and State control, and, if so, what can be done? And, in the second place, we may inquire whether individual citizens, and especially those who have had scientific training, have a duty in the premises.

There is a school of sociologists who hold that the functions of government should be reduced rather than extended; that they govern best who govern least; and that "the good of the nation is attained by inactivity rather than by active exertion of the government, by allowing the individual to work out his own salvation (or damnation) amid the free and unrestricted play of natural forces, rather than making them do so." Such laissez-faire doctrines, however, will hardly appeal. to that more eulightened and healthy public sentiment that regards the function of government as legitimately exercised "wherever co-operation of the whole will accomplish the end aimed at by society better than individual effort." *

* Fernow, B. E., Science, Vol. II., p. 258. 
Now, as pointed out by Dr. Fernow, from whom I have already quoted, government has what may be called providential functions in regard to natural resources. It is the "representative not only for communal interests as against individual interests, but also of future interests as against those of the present. $* * *$ Its activity must be with regard to continuity, must provide for the future, must be providential," and this in the case of such a natural resource as the one under consideration is possible only under the supervision of permanent institutions, with which present profit is not the only motive.

These principles embodied in the scientific forestry of the Old World have resulted in the establishment of a well-nigh perfect system under which in France the sandy wastes of Gascony have been covered with productive forests, and denuded mountain slopes, the play of destructive torrents, have been clothed again with their protective covering of sod and trees; while in the German Empire a clear annual revenue of $\$ 40,000,000$ shows something of what is practicable under State control of forest property.

In the New World, in recent years, one State after another has come to recognize the necessity as well as the reasonableness of government care of the forests, and in several States important legislative enactments have defined the policy and rights of the Commonwealth in this direction.

In the State of New York a law enacted April 25, 1895, provides for a Commission of Fisheries, Game and Forests, with power to appoint thirty-five foresters, whose duty it is to enforce all laws and regulations of the Commission for the protection of fish and game and for the protection and preservation of the forest reserve and all rules and regulations for the care of the Adirondack Park. The law provides further for the care and superintendence of the forest preserve, for protection against fire, actions for trespasses, and for the purchase and taxation of lands belonging to the State.

The New York State Legislature last year appropriated 
$\$ 1,000,000$ for the purchase of land in the Adirondack region, and the State now owns 800,000 acres (out of the 2,500,000 acres) of forest land in that section. This year $\$ 500,000$ will be placed in the hands of the Forest Preserve Board to continue the purchase of forest lands, and part of this sum, it is expected, will be expended in the purchase of 25,000 acres that will be given in trust to the authorities of Cornell University for twenty five years, with the aim of having an experiment in forest preservation and culture tried.*

It is thus with well-matured plans, looking far into the future, that the State of New York has made liberal and farsighted provision for its forest interests, finally calling to the aid of the State the services of the University and giving a quarter of a century in which to ronduct an experiment that can hardly fail to be productive of important results.

The Legislature of Pennsylvania, at different times within the past few years, has passed laws establishing and prescribing the duties of a Forest Commission to report upon the condition of the slopes and summits of the important watersheds of the State, the amount of standing timber, the part or parts of the State where each grows naturally, and to suggest measures for maintaining a proper timber supply. Provision is further made for the enforcement of laws designed to protect forests from fire and for the preservation and increase of the timber lands of the State and for securing forest reservations adjacent to waters draining into the Delaware, Susquehanna and Ohio rivers.

Most instructive, perhaps, on account of similarity of conditions, is the recent history of forest legislation in Wisconsin. The Legislature of 1897 passed a law authorizing the Goveruor to appoint a commission consisting of three members to devise and draw up a plan for the organization of a State forestry department. The plan is to include provisions for the reservation by the State of all lands which are better fitted for the growing of timber than for agricultural pur-

* New York Tribune, February 19, 1898. 
poses, the purchase of similar lands abandoned by their owners and the management and replanting of forests according to the principles of scientific forestry. They are also to draw up a plan by which the forestry department may be from the first self-supporting and in time become a source of revenue to the State.

It was provided that the commission should receive no compensation, but the services of a competent expert connected with the Forestry Division at Washington were secured, and $\$ 500$ towards his actual expenses were provided by the State Geological and Natural History Survey. Mr. Filibert Roth, who was detailed for this work, entered upon his task with characteristic energy, and in a month's journey visited 27 counties with a total area of 18.5 million acres. His report* is of special interest, giving, as it does, a remarkably clear statement of the condition of things over an area embracing fully half of the State of Wisconsin, including 8.5 million acres of cut-over land, most of which is burned over and largely waste, and on which some twenty billion feet of pine has been destroyed by fire. The value of the timber product of former years is suggested by the statement that "the forest industries have built every foot of railway and wagon road, nearly every town, school and church, and cleared half of the improved land in northern Wisconsin."

The discussion of the future of this great area, once a natural forest, now largely a wilderness, necessarily involves great uncertainty. Mr. Roth proceeds to show that in Wisconsin "the hardwoods, though perfectly able under normal conditions to hold their own and continue as forests, have not done so," and "that hemlock has failed to reproduce itself for a long time," while the white pine "is perfectly capable not only to continue as a forest, but also to reclothe old buruedover slashings on all kinds of soil. But it is equally certain that the great mass of pine slashings have remained and will

* Preliminary Report on Forest Conditions in Northern Wisconsin. Washington, 1898. 
continue to remain barren wastes, and that of the $8,000,000$ acres of cut-over lands in north Wisconsiu not one-tenth is stocked with growing timber. And the swamp woods have no future, for it is here among the tall marsh grass and masses of dead poles that most of the fires start.

"In this way an area now nearing 8,000,000 acres, and rapidly increasing in extent, remains unproductive. Counting only 20 cubic feet, or 100 feet B. M., as the annual growth per acre on lands entirely without any care or protection against fire, the State of Wisconsin loses annually by this condition of things $800,000,000$ feet B. M. of marketable saw timber; nor is this all, for even with primitive management this amount could be largely increased.

"The assertion that this land is needed for agriculture, that it soon will all be settled, and that even the sandy soils produce potatoes and are profitably farmed by improved methods, may well be answered by a concrete case. The old settled counties Waushara, Adams, and Marquette have an aggregate area of $1,144,000$ acres; their improved land amounts to 340,000 acres, leaving fully 70 per cent. or 804,000 acres, in brush and waste lands. In 1895 these counties supported wood industries whose product amounted to the pitiful sum of $\$ 13,000$, and probably the material for these was imported, instead of having $80,000,000$ feet of pine to sell, which under simple methods of care might have been derived from these brush and swamp lands."

It will be seen that in this preliminary survey and report an important and valuable contribution has been made, which has opened the problem for further information, demonstrating meanwhile the extent of the interests that are involved in its practical study. The Forestry Commission of Wisconsin fully realizes this, and is actively at work with plans for the future.

The similarity of conditions in the two States and the solid progress already made in Wisconsin suggest that we can probably do no better at present than to adopt substantially 
the same measures. The initial expense to the State is so little as to be hardly worth mentioning, and the end to be obtained is of such far-reaching importance as to warrant, or rather imperatively demand, the earnest work and personal sacrifice that will be involved in this patriotic effort to restore in some measure the forest wealth of Michigan and to make forever impossible the frightful waste of natural resources that has been so conspicuous a feature of our recent history.

It will naturally be asked: Is this all that the Michigan Academy of Science is to do in formulating plans for a Natural History Survey of the State? Workers, many of us, in pure science, are we to rest satisfied with merely formulating a plan by means of which the material interests of the State are to be subserved? Ought we not rather to develop a comprehensive plan by means of which biological relations of every kind shall be brought under scientific investigation? Shall we not leave practical matters to practical men and give ourselves to that to which we were called-our laboratories, our students, and the pursuit of science for its own sake.

Such questions lead finally, as it seems to me, to the answer that the interest of one is in the end the interest of all. Scientific investigation, in Michigan at least, is to a great extent dependent on means provided by the people of the State, who are paying, generally with cheerfulness, sometimes with more or less questioning, for the equipment of the laboratories in which we work. Such is our dependence, let us frankly acknowledge it, and hold ourselves ready to make such return as we are able. On the other hand, the people of the State are dependent-more so, perhaps, than is sometimes admitted-on trained scientific men for the working-out of nearly every problem affecting their material interests. There is not a practical man in Michigan competent alone to successfully work out the problem as to just what the State ought to do in the preservation and profitable management of its forests. Here the services of trained scientific experts are indispensable, and fortunately this University was, eight or ten years ago, en- 
gaged in training the man who is now fitted to render this service and stands ready to do so.

In the second place, a full recognition of material obligation and the taking-up of just such practical problems as this will not hinder, but will pave the way for, the more extended investigation of the natural history of our State that we all hope to see accomplished. It is, I am convinced, the part of wisdom to begin our Natural History Survey of Michigan with this great and pressing problem; but no one could think for a moment that it should end there. Here, as elsewhere, means are certain to be fortheoming as it becomes evident that they are deserved, and I believe that we may to-day begin to plan for just such a comprehensive biological survey of the State as would satisfy the most extended and exacting scientific requirements, assured that in due time we shall have full means for its accomplishment.

I should hardly think of attempting off-hand to draw up a requisition or to unfold a comprehensive plan for such a survey. But there are certain principles, or facts, that through their inherent reasonableness must, I think, command general assent and upon which we may proceed until we can see further.

First, there ought to be within the State a collection of books of such extent that the literature of any branch of natural history may be within the reach of specialists, without the necessity of borrowing or undertaking long and expensive journeys. Such collections of books are a necessity, and the development of scientific work in Michigan will be advanced or hindered according as they are or are not provided. We can not have these books in a day; but we can and ought to make their necessity known, and to use every legitimate means to secure them. The State of Minnesota, in connection with its Natural History Survey, appropriates year after year what would seem to us a munificent sum for the purchase of books that go into the University library and there become permanently available for purposes of research. 
Secondly, there ought to be provision for the publication, by the State, of all material that has assumed sufficiently complete shape to be an actual contribution to our knowledge of the various plants and animals within our borders. Not a little valuable material, to the knowledge of the writer, lies packed away in the laboratories of the State that should be published as a part of its Natural History Survey, that with the assurance of publication in creditable form would be steadily growing, instead of remaining at a standstill. It is, I think, the duty of our Academy to press this upon the attention of the State goverument until the want is supplied.

In the third place, passing now to matters that may be determined largely by individual agreement rather than by State action, we may profitably aim both at greater specialization and more intelligent co-operation. When one has made himself a thorough student in any special field it would seem both courteous and expedient for all of us to recognize that field as his, to send him material that falls into our hands, and to co-operate with him in every way in our power. I do not mean, of course, that a summer or two of amateur work constitutes a claim to pre-empt any special group or subject, nor, on the other hand, that any one should be precluded from doing his utmost in any field whatever to which his choice may lead him, but that we ought to recognize the necessity of a division of labor, and also the fitness of looking to those who for a score of years or a lifetime have carefully worked some restricted field as the natural depository of material, and authorities to whom we may go for help and to whom we may gladly render service in their further studies.

Lastly, the question of organization-by no means an easy one-is best approached by an attentive study of the recent experience of other Commonwealths. If we were starting without traditions, with the virgin soil of a new territory open to us, it would, perhaps, be hardly possible to devise an organization with a more comprehensive, practicable and reasonable working basis than that of the State of Minuesota. 
But we are not starting that way. Our State Survey has its traditions. We have several centers of scientific work instead of one and it is inevitable and desirable that, directly or indirectly, they should have a hand in much at least of the scientific work that in the future is undertaken by the State.

This condition of affairs would perhaps suggest a form of organization similar to that of Indiana, in which a Biological Survey was inaugurated by the Academy of Science five years ago. This has since been adopted by the State, and is quite distinct from the Geological Survey, though working in entire harmony with it, the State Geologist being an active member of the Academy. "In a very short time," says Professor Stanley Coulter, "the work in this survey was felt to be of great importance to the State. An application to the Legislature secured an annual appropriation of $\$ 600$ for the publication of the proceedings. The Academy furnished the material and the editorial supervision without cost to the State. The State, however, prints and provides for the distribution of not less than 1,500 copies annually of the proceedings." We have then, at our door, a successful solution of the question by a State in which the situation of affairs at the inauguration of the Biological Survey was nearly identical with that in the State of Michigan at the present time. We can hardly do better than to learn of our neighbor and move forward.

To recapitulate: It has been the purpose of this paper to formulate and emphasize the following facts:

1. The responsibility of the State for a scientific study of its own natural resources has become fully established by the continuous practice of our own and many other States.

2. Equally well established in theory, and in various States in practice also, is the fact that a Biological or Natural History Survey is of as great importance and has as great claims upon the State as a Geological Survey.

3. The time is favorable in Michigan for undertaking a Natural History Survey; and the State Academy is the natural source from which the movement should originate. 
4. The survey should be projected on a broad, liberal and comprehensive plan, but it should include at the outset a specific problem of practical importance and at the same time of scientific interest.

5. Such a problem is presented in the future of the waste lands once covered by the pine forests of Michigan. It is certain before long to attract enough public attention to become a subject of legislation, and our present attitude may do much to determine the course of events in this direction.

6. Meantime there is every reason in favor of proceeding as rapidly as practicable, along lines already suggested, in the development of our State Biological Survey. This, in fact, if not in form, has long been in progress, as the studies of 'Unionidx in Michigan,' the 'Birds of Michigan,' the 'Michigan Flora,' and various other pieces of work of high scientific merit abundantly testify. But it is time now that the undertaking should be organized, that the State should recognize its duty to this form of scientific work, and that we ourselves should be forming clear conceptions of the problems that, in wonderful, if perplexing, interest, are sure to attend into the twentieth century the Natural History Survey of Michigan. 

THIS BOOK IS DUE ON THE LAST DATE STAMPED BELOW

AN INITIAL FINE OF 25 CENTS WILL BE ASSESSED FOR FAILURE TO RETURN THIS BOOK ON THE DATE DUE. THE PENALTY WILL INCREASE TO 50 CENTS ON THE FOURTH DAY AND TO $\$ 1.00$ ON THE SEVENTH DAY OVERDUE.

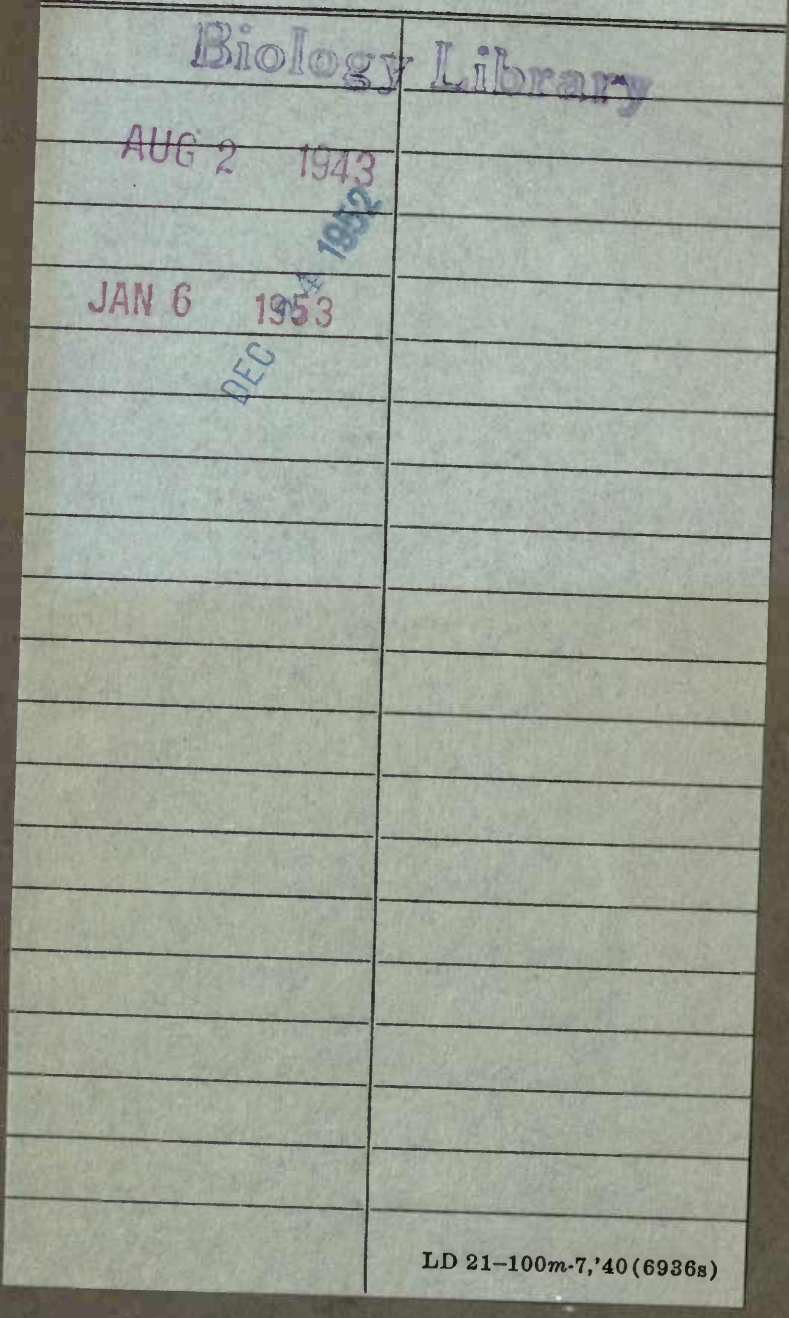


Pamphlet

Binder

Gaylord Bros.. Ine.

Stockton, Calif.

T. M. Reg. U.S. Pat. Off.

\section{0

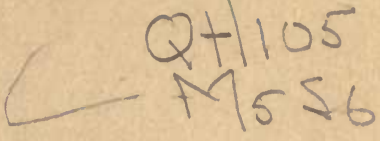

THE UNIVERSITY OF CALIFORNIA LIBRARY 
